American University Washington College of Law

Digital Commons @ American University Washington College of

Law

Articles in Law Reviews \& Other Academic Journals

Scholarship \& Research

2016

The Olmstead Imperative: The Right to Live in the Community and Beyond

Robert Dinerstein

Follow this and additional works at: https://digitalcommons.wcl.american.edu/facsch_lawrev

Part of the Disability Law Commons, and the Supreme Court of the United States Commons 


\title{
The Olmstead Imperative: The Right to Live in the Community and Beyond
}

\author{
Robert D. Dinerstein
}

\begin{abstract}
Of the 20 Americans with Disabilities Act (ADA) cases that the United States Supreme Court has decided in the 25 years of the statute's existence, Olmstead v. L.C. by Zimring is without doubt the most significant for people with intellectual and developmental disabilities. Olmstead is the only Supreme Court ADA case that specifically addresses the rights of people with intellectual and developmental disabilities, but its importance goes well beyond this specific fact. In this essay, I set out the holding of the Olmstead decision, its connection to, and extension of, prior case law, the extent of its subsequent enforcement, and its implications in areas that go beyond the institutional context of the case itself.
\end{abstract}

Key Words: American with Disabilities Act; intellectual and developmental disabilities; Olmstead Act; community-based services; inclusion

Of the 20 Americans with Disabilities Act (ADA) cases that the United States Supreme Court has decided in the 25 years of the statute's existence, Olmstead v. L.C. by Zimring (1999) is without doubt the most significant for people with intellectual and developmental disabilities. Olmstead is the only Supreme Court ADA case that specifically addresses the rights of people with intellectual and developmental disabilities, but its importance goes well beyond this specific fact.

The Olmstead case is noteworthy for its broad recognition of the rights of people institutionalized in congregate facilities to live and receive needed services and supports in the community. Critically, Olmstead endorsed the congressional finding in the ADA that institutionalization constituted discrimination (Americans with Disabilities Act, §12101(a)(3), 2012). At least since the beginning of the Obama Administration, aggressive Executive Branch enforcement, coupled with private litigation, has resulted in a sea change with regard to the perceptions of people with cognitive disabilities and their right to live and thrive in the community. Further, Olmstead is one of those rare cases that is important not only in its own right, and for its specific holding, but also for the possibilities it offers for reform in other areas of importance in the lives of people with cognitive disabilities. In this article, I set out the holding of the Olmstead decision, its connection to, and extension of, prior case law, the extent of its subsequent enforcement, and its implications in areas that go beyond the institutional context of the case itself.

\section{The Olmstead Decision}

Olmstead concerned two individuals, known in the case report as L.C. and E.W., who were people with intellectual and mental health disabilities. Both women were in and out of institutional settings in Georgia and filed suit claiming that their confinement in a segregated environment violated their constitutional right to due process and statutory right to nondiscrimination under Title II of the ADA, which covers public (state and local) services (Jamieson, 2015).

Olmstead was not the first case to argue that individuals with intellectual and developmental disabilities had a right to receive services in community-based settings. The case built on landmark right-to-treatment and right-to-habilita- 
tion cases, such as Wyatt v. Stickney (Partlow in Alabama; 1972), NYSARC v. Carey (Willowbrook in Staten Island, New York; 1975), and others, and lower federal court cases such as Halderman v. Pennhurst State School \& Hospital (Pennhurst, outside Philadelphia; 1977) and Evans v. Washington (Forest Haven, outside Washington, D.C.; 1978). These cases, in the late 1970s and early 1980s, recognized the viability and necessity of community-based care for people with disabilities. The constitutional effect of these cases, however, had stalled after the Supreme Court's 1982 decision in Youngberg $v$. Romeo; and though community-based programs continued to expand as an alternative to institutions, they did so without significant judicial imprimatur.

Fast forward to the passage of the ADA in 1990. As early as 1995, a federal appellate court had concluded that public entities were required to administer services to people with disabilities in the most integrated setting appropriate to their needs (Helen L. v. Didario, 1995). Later that year, the initial Olmstead complaint was filed in federal court. In Olmstead, the lower courts did not address the constitutional question presented, nor did the Supreme Court. Rather, the Court, citing the "integration regulation" issued under Title II of the ADA, concluded that Title II of the ADA banned unnecessary institutionalization as a form of discrimination on the basis of disability. Justice Ginsburg, writing for the Court's 6-3 majority, noted:

Recognition that unjustified institutional isolation of persons with disabilities is a form of discrimination reflects two evident judgments. First, institutional placement of persons who can handle and benefit from community settings perpetuates unwarranted assumptions that persons so isolated are incapable or unworthy of participating in community life. ... Second, confinement in an institution severely diminished the everyday life activities of individuals, including family relations, social contacts, work options, economic independence, educational advancement, and cultural enrichment. . . . Dissimilar treatment correspondingly exists in this key respect: In order to receive needed medical services, persons with mental disabilities must, because of those disabilities, relinquish participation in community life that they could enjoy given reasonable accommodations, while persons without mental disabilities can receive the medical services they need without similar sacrifice. (Olmstead v. L.C., 527 U.S. at 600-01, 1999; citations omitted)

Despite the Court's understanding of the harms of institutionalization, its embrace of the statutory imperative of community-based care was narrower than that of the opinions of the lower courts. The majority did not want to force individuals into community-based settings that they did not seek, nor did it support community placement if professionals did not recommend it. Further, it was concerned that a system of community placements not amount to a fundamental alteration of the state's program for service delivery, which would constitute a defense to the claim of discrimination. Accordingly, the Court held that

under Title II of the ADA, States are required to provide community-based treatment for persons with mental disabilities when the State's treatment professionals determined that such placement is appropriate, the affected persons do not oppose such treatment, and the placement can be reasonably accommodated, taking into account the resources available to the State and the needs of others with mental disabilities. (Olmstead $v$. L.C., 527 U.S. at 607, 1999)

It is worth focusing on the three elements of the Olmstead holding, not only for what the Court wrote, but for what concerns lay behind these elements. The first requirement, that the State's professionals determine that community-based treatment is appropriate, is a tacit reference to the 1982 Youngberg decision, which held that states did not violate the due process rights of institutionalized persons if their professionals exercised professional judgment in their practices and recommendations (Youngberg $v$. Romeo, 1982).

In the years leading up to the Youngberg case, there was far from a consensus among professionals working with people with intellectual and developmental disabilities that all individuals, including people with severe and profound intellectual impairments, could be served in community-based settings (Wyatt $v$. Ireland, 1979). But between the late 1970s and 1999, when Olmstead was decided, almost all professional disagreement about the appropri- 
ateness of community-based treatment for all people with intellectual and developmental disabilities had vanished, so that this first element seemed to be stating a truism rather than marking out controversial territory. The Court was careful in Olmstead not to require community placement when professionals deemed it inappropriate, and seemed to recognize a continued role for institutions that many would not support. But as events have played out, the stance of professionals on community placement has not been an impediment to community integration.

The second element-that the affected persons not oppose treatment-provided a basis for recognizing the value of individual choice, while leaving as an unacknowledged open question what a state must do if an individual under guardianship does not oppose community placement but his or her guardian does. Because the Court viewed community placement conceptually as a reasonable accommodation, it quoted language from the Title II regulations providing that people cannot be forced to accept a reasonable accommodation in support of the proposition that community placement could not be required over a person's objection.

The most controversial element, arguably, was the third one. The state of Georgia had asserted that inadequate funding and not discrimination was the reason for plaintiffs' continued institutional confinement. The lower courts and $\mathrm{Su}$ preme Court rejected this argument, but the latter showed greater sympathy for demands on the state resources, while holding the following:

Unjustified isolation . . . is properly regarded as discrimination based on disability[,] ... We recognize, as well, the States' need to maintain a range of facilities for the care and treatment of persons with diverse mental disabilities, and the States' obligation to administer services with an even hand. ... In evaluating a State's fundamental alteration defense, the District Court must consider, in view of the resources available to the State, not only the cost of providing community-based care to the litigants, but also the range of services the State provides others with mental disabilities, and the State's obligation to mete out those services equitably. (Olmstead v. L.C., 527 U.S. at 597,1999$)$
The Court elaborated on this last sentence by observing that:

If, for example, the State were to demonstrate that it had a comprehensive, effectively working plan for placing qualified persons with mental disabilities in less restrictive settings, and a waiting list that moved at a reasonable pace not controlled by the State's endeavors to keep its institutions fully populated, the reasonable-modifications standard would be met. (Olmstead v. L.C., 527 U.S. at 605-06, 1999)

Commentators and advocates were concerned that this interpretation of the fundamental alteration defense could serve as a brake on deinstitutionalization efforts. That fear has not come to pass. Instead, Olmstead has come to stand for a ringing endorsement of community integration of people with mental disabilities in multiple aspects of daily life.

\section{Beyond the Individual Case}

It is tempting to look at the Olmstead decision from the perspective of the present and conclude that its extraordinary influence was foreordained. But the plenary implementation of Olmstead was far from guaranteed. For one thing, almost from the beginning, commentators, advocates, and policy makers treated Olmstead as if it were in fact a class action rather than a case on behalf of two individuals. (Questioning from the Justices at oral argument reflected this approach, as well.)

The Clinton Administration immediately jumped on the decision as support for its policies. Little more than a month after the decision, Secretary of Health and Human Services Donna Shalala made a speech to the National Conference of State Legislators in which she extolled the decision and stated that it furthered the Administration's ultimate goal, of "a nation that integrates people with disabilities into the social mainstream, promotes equality of opportunity, and maximizes individual choice" (The Center for An Accessible Society, undated). She followed that speech on January 14, 2000, with a letter to all 50 state governors, and a letter from the Health Care Financing Administration to all 50 state Medicaid directors, outlining a framework for implementing Olmstead. (Freedom Clearinghouse, undated).

After the change in administrations, on June 18, 2001, President George W. Bush issued Executive 
Order No. 13217, "Community-Based Alternatives for Individuals with Disabilities," which called on the federal government to assist states to implement Olmstead, adding: "The United States is committed to community-based alternatives for individuals with disabilities and recognizes that such services advance the best interests of the United States" (Disability World, 2001). The Executive Branch's embrace of Olmstead was critical in making sure that the decision stood for more than providing community-based services to two individuals.

As the years went on, some disability advocates saw the Bush Administration's commitment to Olmstead enforcement as far from vigorous (National Disability Rights Network, 2009; Judge David L. Bazelon Center for Mental Health Law, 2009). But with the advent of the Obama Administration in 2009, Olmstead enforcement took off. The Obama Administration announced that 2009 would be named "The Year of Community Living" (Department of Justice, 2015). Under the leadership of Civil Rights Division officials, including its Special Counsel for Olmstead Enforcement, the Department of Justice (DOJ) has brought statewide investigations leading to letters of findings and consent decrees on behalf of people with developmental or psychiatric disabilities institutionalized in Delaware, Georgia, Mississippi, Nebraska, New Hampshire, Puerto Rico, and Virginia (Department of Justice, 2015). These investigations have extended Olmstead beyond individual state institutions to include all of a state's institutions, an enforcement approach as sweeping as federal efforts to address statewide violations of civil rights in the historical realms of education and voting rights. Moreover, the kinds of institutions include not only traditional psychiatric institutions and institutions for people with intellectual and developmental disabilities, but also nursing homes and adult care homes.

Olmstead enforcement is not just the province of the Executive Branch. "The majority of litigation to enforce Olmstead has been brought by legal aid agencies, public interest law firms, and the nationwide network of Protection and Advocacy Systems (P\&As)" (National Disability Rights Network, 2015, p. 9). Moreover, in the Obama Administration, DOJ has frequently issued a Statement of Interest and then sought intervention in private lawsuits bringing Olmstead challenges, reflecting a public-private partnership that has often proved fruitful in large-scale civil rights cases that are highly resource- and personnel-intensive.

\section{Beyond Institutions}

As extensive as statewide enforcement of Olmstead rights in institutional settings is, perhaps the most noteworthy recent development in implementation of the decision is its extension to settings that go beyond residential institutions and community-based residences. One prominent extension has been to sheltered workshops, where both private plaintiffs and the Justice Department have pursued litigation to eliminate this segregated form of work for people with intellectual and developmental disabilities (Lane v. Kitzhaber, 2012; United States $v$. State of Rhode Island, 2014). In 2015, the DOJ sent a letter of findings to officials in Georgia alleging that the state's administration of the Georgia Network for Educational and Therapeutic Support (GNETS) violated Title II of the ADA by unnecessarily segregating schoolchildren with behavior-related disabilities away from their nondisabled peers (Department of Justice, 2015).

Although not yet reflected in case law or executive enforcement, there are other areas in which Olmstead may spur development of more integrated approaches to activities of daily life. Professor Leslie Salzman has argued that Olmstead should be used to challenge states' use of guardianship for people with disabilities as an unnecessarily segregated and restrictive form of decision making for them (Salzman, 2010). Indeed, the increasingly rapid development of supported decision making as a less restrictive alternative to guardianship presents interesting possibilities for using Olmstead in support of what may be the most important component of an adult's life: the right to make choices (Blanck \& Martinis, 2015; Dinerstein, 2011-2012). Voting is another frontier in which the Olmstead focus on community integration could be used to support reasonable modifications in the voting processmodifications that enable people with intellectual and developmental disabilities to participate in the political process as other citizens do.

\section{Conclusion}

American society has come a long way from a district court case brought on behalf of two individual women with intellectual and mental health disabilities in Georgia who wanted to receive the supports they needed in the community, rather than in a regional psychiatric hospital. Through forceful and creative advocacy by individuals, advocates, lawyers, and governmental 
officials, Olmstead has come to stand for a true community imperative. Work in this area is not finished, by any means. As we celebrate this $25^{\text {th }}$ anniversary of the ADA, it is important to recognize this crowning achievement of equality, nondiscrimination, and integration.

\section{References}

Americans with Disabilities Act, 42 U.S.C. §12101 et seq.; $§ 12101(\mathrm{a})(3)(2012)$.

Bazelon [Judge David L.] Center for Mental Health Law. (2009, March). Press Release: Georgia stakeholders ask court to withhold approval of settlement with Justice Department. Retrieved from http://www.bazelon. org/LinkClick.aspx?fileticket=AoNgZUsnJ48\% $3 \mathrm{~d} \&$ tabid $=251$.

Blanck, P., \& Martinis, J. (2015). "The right to make choices": The National Resource Center for Supported Decision-Making. Inclusion, 3(1), 24-33.

The Center for an Accessible Society. (undated). Enforcing the Olmstead decision. Retrieved from http://www.accessiblesociety.org/topics/ persasst/Olmstead_shalala.htm (undated, accessed August 13, 2015)

Department of Justice, Civil Rights Division. (2015). Olmstead: Community Integration for Everyone. Retrieved from http://www. ada.gov/olmstead/ (accessed August 13, 2015).

Dinerstein, R. (2011-2012). Implementing legal capacity under article 12 of the U.N. Convention on the Rights of Persons with Disabilities: The difficult road from guardianship to supported decision making. Human Rights Brief, 19, 8-12.

Disability World. (2001, Nov.-Dec.). Retrieved from http://www.disabilityworld.org/11-12 01/news/olmstead.shtml (accessed August 13, 2015).

Evans v. Washington, 459 F. Supp. 483 (D.D. C. 1978).

Executive Order 13217 of June 18, 2001, Community-Based Alternatives for Individuals with Disabilities. Retrieved from https://www.gpo. gov/fdsys/pkg/CFR-2002-title3-vol1/pdf/ CFR-2002-title3-vol1-eo13217.pdf (accessed December 28, 2015).

Freedom Clearinghouse. (undated). Retrieved from http://www.freedomclearinghouse.com/ know/officialword.htm (accessed August 13, 2015).

Halderman v. Pennhurst St. Sch. \& Hosp., 446 F. Supp. 1295 (M.D. Pa. 1977) (further history omitted).

Helen L. v. Didario 46 F.3d 325 (3d Cir. 1995).

Jamieson, S. (2015, Winter). The Olmstead decision and its aftermath. Impact, 28(1), 18.

Lane v. Kitzhaber, 841 F. Supp. 2d 1199 (D. Or. 2012).

National Disability Rights Network. (2009, September 30). A decade of "little progress" implementing Olmstead: Evaluating federal agency impact after 10 years.

National Disability Rights Network. (2015). Docket of cases related to enforcement of the ADA Title II "Integration Regulation."

NYSARC v. Carey, 393 F. Supp. 715 (E.D.N.Y. 1975) (further history omitted).

Olmstead v. L.C., ex rel. Zimring, 527 U.S.581 (1999).

Salzman, L. (2010). Rethinking guardianship (again): Substituted decision making as a violation of the integration mandate of Title II of the Americans with Disabilities Act. University of Colorado Law Review, 81, 157244.

United States v. State of Rhode Island, No. 1:14cv-00175(D.R.I., 2014, April 9) (consent decree).

Wyatt v. Ireland, Civ. A. No. 3195-N (M.D. Ala., 1979, Oct. 25) (prior and subsequent history omitted).

Wyatt v. Stickney, 344 F. Supp. 387 (M.D. Ala. 1972) (prior and subsequent history omitted). Youngberg v. Romeo, 457 U.S. 307 (1982).

Received 8/14/2015, accepted 8/14/2015.

\section{Author:}

Robert D. Dinerstein, Professor of Law, American University, Washington College of Law, Washington, D.C.

Correspondence concerning this article should be addressed to Robert D. Dinerstein, Washington College of Law, American University, 4300 Nebraska Avenue, NW, Room Y202, Washington DC 20016 USA (e-mail: rdiners@ wcl.american.edu). 